\title{
IAMJ
}

INTERNATIONAL

AYURVEDIC

MEDICAL JOURNAL

\section{AHARA RASA UNVEILED - TRANSFORMATION TO THE FINEST}

\section{Varghese Jibi Thankachan', Vaishali Deshpande ${ }^{2}$, Manna Mathew ${ }^{3}$, Sreelakshmi $\mathrm{S}^{4}$}

${ }^{1}$ Ph.D Scholar, Parul Institute of Ayurveda; Professor, Department of Kayachikitsa,

Dr. D. Y. Patil Vidyapeeth, Pimpri - Pune, Maharashtra, India

${ }^{2}$ Professor, Department of Kayachikitsa, Parul Institute of Ayurveda, Vadodara - Gujarat, India

${ }^{3}$ Final P.G., Department of Dravyaguna, Dr. D. Y. Patil Vidyapeeth, Pimpri -Pune Maharashtra, India

${ }^{4}$ Final P.G., Department of Kayachikitsa, Dr. D. Y. Patil Vidyapeeth, Pimpri -Pune Maharashtra, India

Corresponding Author: vjayu82@gmail.com

\section{https://doi.org/10.46607/iamj4209082021}

(Published Online: August 2021)

Open Access

(C) International Ayurvedic Medical Journal, India 2021

Article Received: 31/07//2021 - Peer Reviewed: 11/08/2021 - Accepted for Publication: 12/08/2021

\section{Check for updates}

\begin{abstract}
Ahara (food) is considered to be Mahabhaishajya or Sarvabhaishajya (best medicine) in Ayurveda and is also considered to be one among Trayopasthamba (3 pillars of life). A Sampoornaahara (balanced diet) should contain all the essential nutrients for the proper growth of the body and mind. Ahara (food) does the Poshana (nourishment) of the Dhatus (body tissues) and food is constantly required after birth for the repair of impaired dhatus (body tissues) and build up new Dhatus (tissues) of excellent quality for good sustainability of quality life. Inappropriate food or faulty food habits can lead to many diseases ranging from a simple skin disease which reflects the improper Rasa dhatu (rasa tissue) to incurable disease of that of Infertility reflecting Shukradhatu. (Defective sperm)
\end{abstract}

Keywords: Ahara Rasa; Shukra; Dhatuposhana; Infertility; Taste; Pathya; 


\section{INTRODUCTION}

Ahara rasa (food essence) production begins with digestion after the process of Jatharagni (digestive fire). This Rasa Dhatu (tissue) further nourishes the Uttarotardhatu (consecutive dhatus) till Shukradhatu (sperm tissue), which later reflects as Garbha (foetus) being the nutrient fraction of Shukra (sperm). This Dhatuposhana (nourishment of dhatus) starts from Garbhavastha (stage of the foetus) where the Ahara (food) consumed by the mother produces Ahara rasa (food essence) which nourishes the Garbha (foetus) and gets a proper formation of organs with all the Saptadhatus (seven tissues). The theories of Dhatuposhana (nourishment of dhatus) are mentioned in the classics as Ksheeradadhinyaya (Law of Transformation), Kedarikulyanyaya (Law of Transmission), KhaleKapotnyaya (Law of Selection.

\section{Rasadraktamtatomamsammamsammedatatoasthi cal} Asthanomajjatatashukramshukratgarbhaprasaadaja $\|(1) \ldots \ldots \ldots . . . \quad$ Ch. Chi 15/16

A sampoornaahara (balanced diet) should have all the essential nutrients for proper growth. No single food or single Ahara rasa (food essence) will provide all essential nutrients for sustaining life. It may result in poor physical and mental health. Overeating of a single food or Ahara Rasa (Taste) may lead to different disease conditions also.

\section{Aim \& Objective}

1. To emphasize and discuss the concept of Aharara$s a$ in Ayurvedic classical literature.

2. To emphasize the importance of Ahararasa in the process of digestion.

\section{Materials And Methods}

This is a review article wherein references of Ahara rasa, Dhatu Uttpatti (Nourishment of dhatus) have been compiled, analysed and discussed for an indepth understanding of Ahara Rasa and its importance in sustaining a healthy life.

\section{The Six tastes in Ayurveda}

Ahara Rasa is the essence of life and affects every aspect of our existence- from structure to physiology, straight through our overall state of mind and con- sciousness. It can be considered a powerful therapeutic tool that ultimately determines the overall flavour of our existence. In the ayurvedic tradition, there is an immense significance of Rasa (taste). Ayurveda recognizes six tastes and is termed as Shadrasa, viz Madhura (sweet), Amla (sour), Lavana (salty), Katu (pungent), Tikta (bitter), and Kashaya (astringent). Each of these has a role to play in our health and wellbeing.

\section{Properties of Shadrasa:}

Madhura (Sweet) - It builds all Saptadhatus (seven tissues) in the body. Apart from giving strength and immunity to the body, it improves complexion, soothes the sense organs and mind and thus increases life expectancy.

Amla (Sour)- This rasa induces appetite and acts as a heart tonic by regulating the function of the heart. It is also good for the digestive system as it increases the digestive Agni (digestive fire) through its Deepana (kindling fire), Pachana (digestive fire) qualities.

Lavana (Salty) - With the intake of this Rasa (taste), it increases appetite and digestion. It imparts moisture and removes blockages in the channels.

Katu (Pungent) - It increases digestion, sharpens and clears all the senses. It has Lekhana (scraping) Shoshana (drying) effect on the body channels.

Tikta (Bitter) - Though untasteful, but it cleanses the oral cavity and causes dryness. It has Lekhana property and detoxifying effects.

\section{Kashaya (Astringent) -}

This rasa purifies the blood and cleans out toxins from the skin. Apart from that, it also aids digestion, does Shoshana (drying)and helps in the healing of wounds. In Ayurveda, the basic concept of drug action is dependent on Rasa Panchaka (properties starting with rasa) that is Rasa (taste), Guna (properties), Virya (potency), Vipak (a metabolite of drug) and Prabhav (specific action). One of the fundamental teachings in ayurvedic tradition is that everything in the universe is a combination of five elements- earth, water, fire, air and space. Even the same applies with Rasa, it contains all five elements with predominantly two elements. Accordingly, these Rasa also causes 
Dosha Vriddhi (increasing of doshas) and Dosha Shaman (decrease meant of doshas) as per their qualities in it.

"Rasa swaduamlalavanatiktoshanakashayaka Shad dravyamashritatetuyathapurvambalavahall Tatradyamaruthamghnanti, trayasthiktadayahakapham| Kashayatiktamadhurahapittamanyetukurvate" $\|^{2} \quad$ (A.H.Su 1/15) “Tatrabhumyam- bugunabahulyanmadhura, bhumhyaagnigunabahulyatamla| Toyaagnigunabahulyatlavana, vayavyaagnigunabahulyatkatukaa, vayavyaaakashgunabahulyattikta, prithvyaanilgunabahulyatkashayaiti || tatra, madhuramlalavanavataghna, madhuratiktakashayapittaghna, katutiktakashayashleshmaghna" $\|^{3}$

( Su.Su. 42/3-4)

Table 1: Rasa - Panchabhoutikatva, DoshaVruddhi \& Shamana (properties of taste)

\begin{tabular}{|l|l|l|l|}
\hline $\begin{array}{l}\text { Rasa } \\
\text { (taste) }\end{array}$ & $\begin{array}{l}\text { Panchabhoutik Constitution-five } \\
\text { major elements }\end{array}$ & $\begin{array}{l}\text { Dosha Vriddhi } \\
\text { (Increased humors) }\end{array}$ & $\begin{array}{l}\text { Dosha Shamana } \\
\text { (Decreased humors) }\end{array}$ \\
\hline Madhura (sweet) & Prithvi \& Jal (Earth \& Water) & Kapha (phlegm) & Vata Pitta (air, bile) \\
\hline Amla (sour) & Pritvi \&Tejas (Earth \& Fire) & Kapha Pitta (phlegm, bile) & Vata (air) \\
\hline Lavana (salty) & Tejas \&Jal (Fire \& Water) & Kapha Pitta (phlegm, bile) & Vata (air) \\
\hline Katu (pungent) & Tejas \& Vayu (Fire \& Air) & Vata Pitta (air, bile) & Kapha (phelgm) \\
\hline Tikta (bitter) & Akasha \& Vayu (Space \& Air) & Vata (air) & Pitta Kapha (bile phlegm) \\
\hline Kashaya (astringent) & Prithvi \& Vayu (Earth \& Air) & Vata (air) & Kapha Pitta (phlegm bile) \\
\hline
\end{tabular}

Table 2: Showing Rasa causing Vriddhi Shamana of Dosha (properties of taste)

\begin{tabular}{|l|l|l|}
\hline Dosha & Vriddhi & Shamana \\
\hline Vata (air) & Katu, Tikta, Kashaya & Madhur, Amla, Lavana \\
\hline Pitta (bile) & Amla, Lavan, Katu & Tikta, Kashay, Madhur \\
\hline Kapha (phlegm) & Madhur, Amla, Lavana & Katu, Tikta, Kashaya \\
\hline
\end{tabular}

The sequence of intake of Rasa in healthy condition

According to Ayurveda, there is a sequence of Rasa (taste) in food to be followed to maintain a healthy mind and body.

"Purvammadhuramashniyayatmadhyeamlalavanouraso |

Paschataeshaanrasaanvaidyobhojaneshuavacarayet" $\|^{4} \ldots . . \quad$ Su.Su 46/460

“Manojnamshuchinaatushnampratyagrasamanamhitam

Purvammadhuramashneeyanmadhyeamlalavanaourasau

Paschansheshanrasaaanvaidhyoubhojaneshvavacharayeth."

"Ashneeyattanmanabhutvapurvamtumadhuramrasam

Madhyeamlalavanaupaschatkatutiktakashayakam"........... ${ }^{5}$ Yogratnakar
During Aharasevana (food intake) the following rule has to be followed:

1.Madhurarasatmakahara (food items predominantly with Madhura Rasa) - at starting of the meal

2.Amla Lavanarasatmakahara (food items predominantly with salty and sour taste)-at the middle of the meal

3.Katu-Tikta and Kashaya Rasa (food items predominantly with pungent, bitter, astringent tastes.)-at the end of the meal.

The logical reason behind this is:

- Before intake of food, our stomach is empty and due to this Laghu (light), Ruksha (dry) qualities of Vata (air) and Ushna Guna of Pitta aggravates. So, to maintain Vata (air)and Pitta (bile) Dosha (humour) Madhur Rasa (sweet taste) is taken first as it is having the Panchabhautik (five major elements) constitution of Prithvi and Jala 
and opposite qualities that of Guru (heavy), Snigdha (unctuous) and Sheeta (cold).

- In middle, both Amla (sour) and Lavana (salty)rasa is consumed because these Rasa (taste)increases the taste of food and these Rasa (taste) possess Snigdha (unctuous)and Ushna Guna (hot property) which makes the food moist and digestible by maintaining acid level normal in stomach and duodenum. It also pacifies Vata Dosha (air humour). The Panchabhautik (five major elements) constitution of Amla Rasa is Prithvi and Teja and that of Lavana Rasa is Jala and Teja and thus it maintains the digestive fire.

- At last, Katu Tikta Kashaya Rasa is to be consumed. After intake of food, there is a necessity for proper digestion and absorption from the gut. These three Rasa helps its functioning like Ushna Guna of Katu Rasa for digestion purpose. Sheeta Vishada (clear) Guna of Tikta Rasa (bitter taste) to avoid excessive Snigdha Guna (unctuous property) in the intestines and maintains Pitta (bile) at normal condition. Laghu (light) Ruksha (dry) Guna (property) of Kashaya Rasa (astringent taste) to absorb the digested material from the gut wall. The Panchabhautik (five major elements) constitution of Katu Rasa is Agni and Vayu, Tikta Rasa is Akash and Vayu and of Kashaya Rasa is Prithvi and Vayu.

In the Samprapti (pathogenesis)of disease, due to improper food ingestion, it causes vitiation of Doshas ie Kapha Dosha in Amashaya, Pitta Dosha in Pachyamanashaya (gastro intestine) Vata Dosha in Pakvashaya. The Dosha vitiation takes place after ingestion of Apathyaahara (incompatible foods).

This order of Rasa changes as per pathology or diseased condition. In Kaphaja Vyadhis (diseases caused by vitiation of phlegm, Katu (pungent) Tikta (bitter) and Kashaya (astringent) Rasatmak Ahara (food predominantly of the tastes mentioned here) is advised. In Pittaja Vyadhis (diseases caused by vitiation of bile) Tikta, Madhura and Kashaya Rasa and in Vataja diseases (diseases caused by vitiation of bile) $L a$ vana, Amla, Madhura Rasa respectively. Therefore, the Guna of Rasa (properties of taste) is having important in manifestation as well as curing the disease. Treating Diseases with the knowledge of Rasa-

When the Shareera (body) is observed as a whole we can logically prove the treatment of any disease pertaining as per the Sthanavishesha (specific location). The upper body indicates the Kaphasthana (location of phlegm), the middle as Pitta Sthana (location of bile) and the lower as the Vatasthana (location of air) respectively. If we plan a treatment considering the Sthanavishesha (specific location), Vatasthana (location of air) and the disorders related to Vatasthana (location of air) should be treated with Madhura Rasa (sweet taste). The Pittasthana (location of bile) and the disorders related to Pittasthana (location of bile) should be treated with Amla Rasa (sour taste) and Lavana rasa (salty taste), and lastly considering the Kapha Stana (location of phlegm) and the disorders related to the Kaphasthana (location of phlegm) should be treated with Katutikta (pungent, bitter taste) and Kashaya rasapradhandravyas.

Similarly, Rasa (food essence), Rakta (blood), Mamsa (muscle), Meda (fat), Asthi (bone), Majj (marrow), Shukra (sperm) are the Saptadhatus (seven tissues) and these tissues are regularly formed getting their nutrition from the food we take, destroyed in due course of time and once again replaced. The quality and quantity of food, discipline in the timing of food, the strength of the digestive fire within, digestion, absorption, conveyance, and transformation of nutrition in the cells, all contribute to tissue health.

"Tathaapyapampradhanatvat rasa soumyo-
abhidhiyate |
atiriktagunaraktevanhemamsetuparthiva $\|$
medasyaambubhuvoasthiprithivyaanilatejasaam |
majjishukre ca soumasya $\| " \ldots \ldots . . .$.

The Panchabhoutika (five major elements) constitution of Saptadhatu (seven tissues) as per the above shloka (verse) is that Rasa Dhatu (the essence of food) is Jala Mahabhutapradhan (predominantly of water), Rakta (blood) is Teja, Mamsadhatu (muscle tissue) is Prithvi (earth), Asthidhatu (bone tissue) is Prithvi (earth), Vayu (air) and Teja (Agni) and that 
of Majja (marrow) and Shukra (sperm)is jalamahabhutapradhan (predominantly of Jala mahabhuta). Thus we can say that Rasa (food essence) has similar properties as that of Kapha (phlegm), Rakta (blood) has similar properties as that with Pitta (bile), Asthi (bone) with that of Vata (air), and rest with that of Kapha (phlegm). So as a hypothesis we can say that while we treat diseases about Rasa Dhatu, (food essence) its Moola (root) being Hrdaya (heart) we can administer Dravyas (substances) like Amalaki (Emblica Officinalis), which are Amla Rasa (sour taste) and work as Hrdya (cardiotonic). Twak (skin)is the Adhisthana (base) of Rasa Dhatu (food essence), skin diseases or Vrana (wound) can be easily treated with Kashaya Rasa Dravyas (astringent substances) And similarly while treating Shukradhatu (sperm tissue) disorders like azoospermia, we can use Kaphavardhaka Madhurarasatmaka Dravyas (substances predominantly with a sweet taste which increases phlegm) like Gokshura (Tribulus Terrestris), Shatavari (Asparagus racemosus) etc. to nourish the Shukradhatu (sperm tissue). The same treatment protocol can be accepted with Rakta (blood)and pitta (bile)because they have Ashrayaashrayee Sambandha (property of dependency). So, Kashaya, Tikta and Madhurarasatmaka Dravyas (substances containing sweet taste, astringent taste and bitter taste) like Guduchi (Tinospora cordifolia), Manjishta (Rubia cordifolia) etc. can be given in Rakta -Pittaja diseases (caused by blood and bile). Mamsa, Meda, Majja are also dependent on Kapha (phlegm), so any disease about them can be treated with Tikta, Katu Kasaya dravyas. (Substances containing bitter, pungent, astringent)

\section{DISCUSSION}

Among Rasa Panchak (properties of rasa starting with rasa), Rasa is the main factor that comes in contact with the Doshas (humour) present in the gastrointestinal tract after its administration. So, at first changes occurs in the quality of Doshas (humour) and due to its vitiation, Dhatu and Mala (waste) get vitiated and due to its change, it manifests as a disease. In various classics, it has been mentioned that if Pathya (proper food) is taken, then there is no need for medicine, and if proper food is not taken, then any medicine taken won't be effective.

"Pathye sati gadartasyakimoushadhanishevanaihi. Pathyeasatigadartasyakimoushadhanishevanaihi”"| (vaidyajeevanam 1/10)

“Na tupathyavihinasyabhesajanamshatairapi”| (Yogratnakar)

Only Pathyaahar (combatible food) and Vihar (regimen)can cure diseases, but one who does not follow Pathya (combatible food) cannot be cured by the use of hundreds of medicines.

Thus, we can say no medicine is equivalent to food, and it's possible to make a person disease-free with just a proper diet.

\section{CONCLUSION}

The human body is the product of food. One should regularly consume food that is conducive for the maintenance of good health and is capable of preventing diseases. Most of the incurable diseases are produced due to improper food. Ahara, Nidra, Brahmacharya are (food, sleep, abstinence) recognized as the three Upasthambhas (3 pillars of life) essential for the smooth running of life. Among these three, Ahara is the best sustainer of life. Every substance is possessing one or two tastes predominantly of six tastes. Thus, we can say Ayurveda teaches us to fully acknowledge, appreciate and even relish the variety of flavours we encounter throughout the day.

\section{REFERENCES}

1. Bhahmanand Tripathi, Caraka Samhita of Agnivesa, Hindi Commentary, Chaukhamba Subharati Prakashan, Varanasi, Edition 2002, Volume 2, Page no 553.

2. K.R. Srikantha Murthy, Vagbhata's Astanga Hrdayam, English translation, published by Chaukhamba Sanskrit Series Office, Varanasi, Volume 1, $8^{\text {th }}$ Edition 2011, page no:144 -147

3. K.R. Srikantha Murthy, Illustrated Susrutha Samhitha, English translation, published by Chaukhamba Orientalia, Varanasi, volume 1 reprint edition-2012, page no:295-296.

4. K.R. Srikantha Murthy, Illustrated Susrutha Samhitha, English translation, published by Chaukhamba Orien- 
talia, Varanasi, volume 1 reprint edition-2012, page no 445

5. Bhishakratna Sribrahmashankar Shastri, Yogaratnakar, Vidyodini Hindi Teekasamhitha, published by Chaukhambha Sanskrit Samsthan, $7^{\text {th }}$ edition:2002, page no:67

6. Vaidya Jadavji Trikamji Acharya, Susruta Samhita of Susruta with Nibandhasangraha Commentary, of Shri Dalhanacharya, Chaukhambha Orientalia, Varanasi, Edition no 9, 2007, page no 69.

\section{Source of Support: Nil \\ Conflict of Interest: None Declared}

How to cite this URL: Varghese Jibi Thankachan et al: Ahara Rasa Unveiled - Transformation To The Finest. International Ayurvedic Medical Journal \{online\} 2021 \{cited August 2021\} Available from: http://www.iamj.in/posts/images/upload/1862_1873.pdf 